\title{
Virtue or Vice? Trauma Reflected in Mo Yan's Frog
}

\author{
WANG JINGHUI
}

\begin{abstract}
The preoccupation with human nature is deeply rooted in literature. This paper starts from the ancient Chinese rudimentary understanding of human nature, then passes through Mo Yan's Frog, an epistolary novel which covers the 30-year history of the Chinese population control policy through the description of an obstetrician in quest of her own human nature, and ends with her mediation and effort to retrieve goodness in the face of state will. Mo Yan, as well as many other Chinese people, does not deny that the onechild family policy had been laid down with a good intention to promote the general welfare of all citizens in China. But through a detailed reading of the novel Frog, it is argued that this policy might be a legalized illegality, which results in the schizophrenia of the main character out of the dilemma of justifying her deeds as virtue or vice. It is suggested that the experience of the female character in the novel, as well as in the contemporary Chinese society, should be investigated allegorically, and it reveals a universal issue about the complexity of human nature, for in a certain sense, one may start aiming to be Mother Theresa, but end in finding himself or herself merely a devoted clownlike servant of the state will.
\end{abstract}

Keywords: human nature; state will; schizophrenia; legal illegality; virtue or vice

The notion of "human nature" has attracted and puzzled human beings for centuries. Firstly, it is hard to define. Scholars and philosophers have not even found the answer to the puzzle of "who am I", not to mention "what is my nature". The corpus of world literature, in a certain sense, is a tentative answer to the inquiry of human being's human nature. Secondly, it is hard to study human nature, which is an abstract and indescribable matter. There have been numerous books on this topic written by philosophers such as Plato, Aristotle, Descartes, Hume, Hobbes, Pufendorf, Rousseau etc. And this preoccupation is not only observed in western countries, but also in the eastern part of the world. To take China as an example, besides adult scholars meditating on human nature, people of other ages have also been alerted to this issue based on the idea passed on from ancient times. Three Character Primer is not in the category of the traditional six Confucian classics, but it 
is the embodiment of Confucianism suitable for teaching young children. For most toddlers in China, the first six characters of Three Character Primer they are taught to recite are "ren2 zhil chul, xing 4 ben 3 shan4" (人之初, 性本 善) $)^{1}$ which means that "human beings are born with good nature" and then the following six characters (xing4xiang1jing4,xi2xianglyuan 3 , 性相近, 习相 远) explain that even though human beings have a similar nature, it varies in different environments. After these kids have entered middle school, they are told to translate the ancient saying: “Shang4 shan 4 ruo 4 shui3" (上善若水) by Lao Tse, which means "The tendency of people's nature to do good is like the tendency of water benefiting others". The Book of Changes, the fundamental philosophical work in China, argued that a person should "strengthen oneself without stopping, and hold the world with virtue", which is also believed to be the credo of the whole Chinese nation (Zhang 1988: 93). All these cases exemplify that the ancient philosophical ideas still exert influence on modern Chinese people.

The essence of these ideas emphasizes not only the concept that human nature is born to be virtuous, but also the concept of "man" or "self", which is the fundamental concept of western philosophies elaborating on human nature. As this article aims to probe into the issue of human nature from the perspective of legal illegality, it seeks a theoretical buttress from a jurist philosopher, Samuel Pufendorf. Pufendorf points out in his book On the Duty of Man and Citizen According to Natural Law that "Man is an animal which is not only intensely interested in its own preservation but also possesses a native and delicate sense of its own value" (Pufendorf1991: 61), because men also have duties to others. He summarizes this part of human nature into three levels: 1) doing no harm to others; 2 ) recognizing men's natural equality; 3 ) being useful to others" (Pufendorf1991: 56-67). Based on the notion extracted from Pufendorf's book, this article examines the actions and beliefs of the main character, Gugu, in Mo Yan's novel Frog ${ }^{2}$, analyzing the relationship between her duty as a natural human being and as a citizen, so as to find out to what

1 As these sayings are the most common expressions used daily by Chinese people, and appear in numerous books, this article does not offer the reference page specifically. For those who want to read the complete version, the Chinese title of the books are 三字经 (Three Character Primer), 道德经 (Dao Te Ching), 易经 (The Book of Changes or The I Ching).

2 All the citations from this novel are out of Howard Goldblatt's translation (Mo Yan, Frog, London: Penguin Group, 2009), and will be indicated with page number after the citation, without being listed separately. 
extent human nature is mingled with public policies, and how to protect the virtue in human nature.

According to Mo Yan, this novel is dedicated to his aunt - the daughter of his great-uncle. It is told in an epistolary style, containing five parts: four letters and one play, through which the Narrator, Tadpole, introduces to his Japanese friend, Sugitani Akihito sensei, the life story of his aunt (also named Gugu, or Wan Xin), especially her working experience as an obstetrician from 1953 onwards. According to Gugu herself, she had delivered more than 10,000 babies, yet she had also aborted more than 1,000. All the forced abortions were carried out due to the implementation of the state one-family-one-child population control policy. "Baby" is the central theme of the novel, and partly results in the title of this novel "frog". The title Frog or "Wa" (蛙) has multiple meanings. Phonologically speaking, it has three denotations: First, it is about babies, as it sounds the same as "wa” (娃), a Chinese character meaning "baby"; second, it is about the sadness of babies, as “wa” (哇) is also an onomatopoeia describing the crying sound of the babies; Third, it is about creation, as "wa"

娲 is a homophone and part of the name "nv3wal", the goddess in Chinese folklore who is believed to be the creator of human beings. And the last denotation also leads to an anthropological understanding of the title: "frog", for not only in Gaomi Town, the setting of the novel, but also in many other Chinese villages and towns, frog is a totem symbolizing fertility. However, ironically, this novel narrates a nation going from fertility to infertility in procreation. The following paper will be developed according to the stages of the mental changes of Gugu, the protagonist of the novel.

\section{Starting as a Baby Sending Bodhisattva - Virtue of Maternal Love Omnipresent}

Before the one-child policy was carried out in $\mathrm{China}^{3}$, Gugu was once considered a baby-sending bodhisattva who helped deliver little miracles to local families. She enjoyed her role as a midwife, eager to offer her help to the pregnant women and felt satisfied hearing the crying of the newly born babies. Moreover, she not only helped human beings, but even helped a water buffalo deliver a calf. In the case of helping the calving water buffalo, there emerged three revelations concerning the virtue of maternal love, one of which is from

3 In 1979, the one-Child policy was introduced to control China's exploding population. In 2002, birth-planning laws were further enforced, which means that if one does not obey the population control policy, he or she becomes a law-breaker. 
the animal, and two from the other female characters. The first revelation comes from the water buffalo. On seeing Gugu, the savior of her coming calf, the water buffalo knelt down immediately, which shows a natural instinct of all animals in this world - priority of the offspring and absolute concern for their own babies. This maternal love is also observed through mother water buffalo's motherly licking of her calf afterward. In Chinese, when describing how deeply parents love their children, people usually use a proverb (tian3du2zhilqing2, 硚犊之情) which compares human parental love to that shown through the cow's licking her calf. The second revelation comes from Tadpole's mother. When Tadpole's father doubted the rationality of asking Gugu, an obstetrician, to help deliver a baby animal, Tadpole's mother uttered a sentence of eternal truth: "The principle is the same."4 (28) It is through a plain Chinese peasant woman's mouth, that a plain but universal belief is expressed: animals and human are equal, and they could, as well as should be treated equally.

The third revelation comes from Gugu. When she saw the water buffalo kneeling down, tears came to her eyes. At that time she was still capable of extending her sympathy to a mother, though a maternal animal, and could feel the water buffalo's eagerness and care for her calf. She calmly helped the endangered water buffalo deliver her calf safely. But Tadpole's father in the novel represents an antagonist who does not follow this principle of equality:

"With whoops of delight we ran inside, where we saw a little sticky coated creature on the ground behind its mother. Wonderful, Father announced excitedly, it's another female!

Isn't strange, Gugu seethed, how men pull a long face when a woman gives birth to a girl baby, but grin happily if a cow does the same thing.

When this calf matures, she'll have calves just like her, Father said.

What about humans? Gugu countered. When a girl matures, she'll give birth to girls, also just like her.

That's different, Father said.” (29)

Tadpole's father was excited to find the newly born calf to be female because it means that more calves would be born in future, but Gugu sharply pointed out a phenomenon that men were happy when the water buffalo gave birth to a female calf instead of a male one; however, they would not be cheerful if their wives gave birth to a baby girl instead of a boy. When Tadpole's father responded that female calf and female babies were not the same, Gugu became

4 For this sentence, the literal translation of the Chinese version could also be "The truth goes the same with both men and animals.” (“人畜是一理”). 
furious to such a strong degree, that Tadpole's father dare not challenge her any further. Gugu at this time believed in the equality between animal and human, and also supported the equality between male and female. She was full of expectations for her bright future life.

\section{As a Policy Implementer - Virtue of Human Nature on the Wane}

The Chinese economic reform, also known as the Opening-up Policy, has fostered a renewed version of traditional Chinese beliefs (Mitchell and Duran 2014: 195-212), but at the same time the benign aspect of human nature and the respect for individuals' basic right were left in jeopardy. After the family planning policy was adopted, Gugu who used to believe in equality and human fraternity was transformed into a devil, fanatically supporting and carrying out the state policy by implementing it with forced abortions and sterilizations. It is hard to imagine that this was the same individual who once tearfully took care of a pregnant water buffalo. There are more signs showing that her benign human nature was on the wane, echoing Rousseau's saying that "we do not know what our nature permits us to be" (Rousseau 1979: 37).

Again, as mentioned above, the Three Character Primer points out that the environment makes the inborn good nature differ dramatically. The environment around Gugu appears to have had a negative effect on the development of her benign nature, and there are three key events that effectively shape the development of Gugu's judgment of morality. The first event originates from her love affair with a pilot, Wang Xiaoti. She had worked very hard, joined the communist party at a very early age, was highly respected by fellow town people, and most importantly, she had a pilot boyfriend. When everything went on smoothly around her, the first fatal setback in her life arrived: her pilot boyfriend deserted her and flew to Taiwan. To her and all other town fellows, it was incomprehensible how Wang Xiaoti could betray his own country. According to them, the government had offered him the highest level of acknowledgement: the highest salary which enabled him to buy a watch ${ }^{5}$ for his girlfriend - Gugu; bountiful supplies of delicious foods (while others were starving), and superb working conditions admired by all. It is evident that he did not side with Communist China, but is it also obvious that he did not love his girlfriend? The answer from the novel is negative. Firstly, while dating Gugu, this pilot affectionately took care of her, and also her family members.

At that time, to have a watch is like having a Porsche nowadays, which is a luxurious possession. 
Secondly, it says in the novel that in order to get his girlfriend out of political torture, before flying to Taiwan the pilot might have made up a diary in which he wrote curses about her and her family members, such as his calling her a piece of "red blockhead", because she followed the red communist party without any reasoning. And the diary did save Gugu, for it was after reading this section of the diary that the authorities concluded that Gugu was not a traitor and could continue working as an obstetrician. Thirdly to study deeper this case, it can be found that the key factor separating this couple comes not from their own internal factors, but from the external statehood. The young man favors the ideology of the Nationalist Party in Taiwan, while the young woman favors that of the Communist Party.

In this situation, the duty of a citizen comes into the frame. As the citizens of the state, one has to surrender his or her personal will to the will of the state. According to Thomas Hobbes, men's descent into powerlessness was voluntary: in order to escape the violence of internecine warfare and attack from the others, men had to yield up to the state the right to use physical force, thereby entering the statehood. Those who chose to stay outside the law of the state become outlaws: "Every citizen retains as much liberty as he needs to live well in peace, [while] enough liberty is taken from others to remove the fear of them ... To sum up: outside the commonwealth is the empire of passions, war, fear, poverty, nastiness, solitude, barbarity, ignorance, savagery; within the commonwealth is the empire of reason, peace, security, wealth, splendour, society, good taste, the sciences and good-will." (Hobbes 1998: 115-116) But there is a potential danger that when men have handed over power to the state, they may not be able to take it back and their own will to be true to their now nature is left in jeopardy. Thus, since China has been divided into two sections of different political regimes, one of Communists, the other of Nationalists, people are forced to choose only one of the two. Wang Xiaoti chose the state of Nationalists, and became an outlaw to Gugu who chose the other. From this perspective, it could be said that Gugu had become the victim of statehood. Unfortunately, Gugu, in that situation at that time, did not realize that she was a victim, instead, she was grateful to the trust from the government and Communist Party, for they believed in her and let her continue her medical practice.

Her attachment to her statehood strengthened further after she countered the second fatal spiritual attack. As she was trying her best to recover from the humiliation caused by her pilot boyfriend, she suffered another one from her colleague, Ms. Huang, who accused her of continually associating with her pilot boyfriend in Taiwan with some so-called poster proofs. To show her loyalty to 
the party and the government, she cut the artery of her left wrist and wrote her will in her own blood: "I hate Wang Xiaoti. I have always been a Party member, and I will die a Party Member." (58) In order to be accepted by the Party, she chose to prove her loyalty with her death. Her suicide attempt was seriously condemned by the party branch of her hospital, but the leader of the hospital comforted her that Communist Party believed in her more than in that accuser, as Gugu was from proletarian class ${ }^{6}$, while the accuser was from land owning class. Hearing these words, Gugu cried heartedly and then devoted herself more to the commitment of the Communist Party.

Then came the Cultural Revolution and the third crucial event that results in Gugu's supreme obedience to the state policy (or the Communist Party policy, as in China, the Communist Party plays the key role in state administration). Because of the historical reason concerning her former boyfriend in a suspicious region, she was dragged to the tall platform in front of the public, "denounced" by the revolutionary masses and branded as a special agent, a counter-revolutionary, and even a harlot. The first two labels Gugu could accept but the label of "harlot", she could not take. To protest against this humiliation of her dignity, she refused to carry the broken shoes that a female Red Guard put on her neck and scratched Yang Lin, the man who had surrendered to the torture of the Red Guards and admitted that they had committed adultery. On the surface, Gugu is supposed to hate the state or Communist Party after being treated with so much humiliation and brutality; however, despite the ruthless torture she suffered, Gugu remained a loyal Party member. One tentative explanation is that Gugu has somewhat become the victim of the Stockholm Syndrome, and the minute difference is that the captor is not a human, but the state.

In the period of "Bringing Order out of Chaos" after the Cultural Revolution $^{7}$, Gugu returned to her job and was assigned the task of helping implement the one-family-one-child population control policy which started in 1979. While the concept of limiting couples to only one child may be an anathema to people believing in personal liberty and freedom of choice, the plain fact here is that some sovereign nations would consider that they have the right to adopt

6 Class origin was of crucial importance before and during the Cultural Revolution in China. The proletarian class, including poor and middle-poor peasants were the leading class of the country, and students of a rich peasant or landlord origin would be deprived of the right to go to college and they were not supposed to be trusted by the government either.

7 The Period of "Bringing Order out of Chaos" started in 1978 and ended roughly in 1982. 
such measures and pass such laws that, in their opinion, could promote the general welfare of their own country, and subsequently the whole world. As a Party member, Gugu thought highly of this policy, believing unequivocally that its primary purpose was to help China cope with the problem of population explosion. She highly recommended the necessity of population control policy: "If we let people have all the babies they want, that's thirty million a year, three hundred million a decade. At that rate, in fifty years the Chinese population alone would flatten the earth. So we must lower the birth rate, no matter what it costs. That will be China's greatest contribution to humanity." (145) There was even an image of contrast in her mind that while the Chinese were endeavoring to control the birth rate so as to benefit the whole world, people in many other countries were producing babies irresponsibly. With this sense of superiority and loyalty to the state, Gugu burned with "insatiable thirst" for annihilating "illegal" babies, with the same kind of violence that she had suffered from before.

Aristotle maintains that the origin of the city-state is that it enables us to live; its justification is that it enables us to live well (Wallas 1948: xix). It is accepted that for the sake of the welfare of all citizens, the government should put forward the one-child policy, but there should be a difference between measures of forced population control and voluntary choice. So far, Chinese government has done well in the aspect of providing contraceptive devices or information to Chinese citizens. But not allowing people to have their own children has violated basic human rights - rights of procreation. Stemming from the premise of breaking the natural law, this population policy cannot guarantee that the police-functioning population-control officials will not break laws. Gugu's vicious behavior is a typical example of breaking the law to enforce it.

How Gugu participated in a crime while implementing the state policy could be exemplified by her dealing with Wang Renmei, Tadpole's wife who was determined to have another baby. So after giving birth to a baby girl, she planned secretly to have a baby boy. Then her second pregnancy set her against the state policy. People around her stood on two sides: one side, including her parents and some town fellows, supporting her will to have another baby, ideally a boy; the other side, including Narrator Tadpole, Gugu and Tadpole's Army branch, insisting on her obeying the state law. Wan Renmei believed that she had the right to determine whether or not to have her own baby. But to Tadpole, who was on the waiting list of being promoted in the army, having a second child meant his being dismissed from the army and the Communist Party, and he could not accept his wife's suggestion of giving up all to come back to work 
as a peasant. In order to enjoy the welfare of the state, he stood beside Gugu to persuade his wife to have an abortion. Wang Renmei fled and hid herself in her own parents' home. Guessing shrewdly that Wang Renmei might hide there, Gugu had her population control team besiege Wang's parents' house, with hundreds of villagers looking on. First, she assigned Tadpole to go into the house to inform his wife that even if he himself wanted to give up his job and all the welfare, she still needed to have the abortion, because the case had reached the higher official branch. Tadpole's cowardly behavior was severely scolded by his parents-in-law, and they also reminded him that the fetus was seven months old and the abortion at this stage was extremely dangerous. But this generated no sentiment in Tadpole. When talking about education and sentiment, Rousseau once emphasized the importance of sentiment: "We have been made an active and thinking being. It remains for us, in order to complete the man, only to make a loving and feeling being - that is to say, to perfect reason by sentiment" (Rousseau 1979: 203). Backed by the state family control policy, Tadpole failed to reason with sentiment about his own function of being a responsible father, or being a caring husband and he insisted that Wang Renmei should have the abortion, and, of course, got no consenting response.

Seeing that Tadpole's persuasion did not work, Gugu, having already lost her sentiments long before, started using her strategy. She spoke through a loudspeaker propagating the state one-child policy to Wang Renmei and her parents and claiming that they had broken the law. She threatened to tear down the trees and the houses of the neighboring family first, and then the houses belonging to Wang's parents, if she still refused to walk out of the house to have an abortion. And what she said was not only threatening words as she did pull down the neighbor's tree first. Then all neighboring families started worrying about the safety of their own property, and they stopped being on Wang Renmei's side, all running to Wangs' house, kicking open the door, cursing their stubborn daughter and threatening to burn Wangs' house if Wang Renmei did not come out. Hurt by her husband's indifference and frustrated by the threat from Gugu and the neighboring families, Wang Renmei came out and went to the hospital with Gugu. Among these people, only Wang Renmei bravely stuck to her morals. She came out not because she chose to surrender to the state policy, but because she did not want to bring harm to others. The real virtue or civilization is to think from others' perspective and bring no trouble to others. In this aspect, Wang Renmin sets an exquisite example. Confronted with the power of the state, she tried her best to retain her own virtue. But tragically, having surrendered her will of having another baby to the state's will, 
she still died in the process of abortion because the fetus had grown too big for the operation.

The death of Wang Renmei did not stop Gugu's fanatical craze about the government's one-child policy. She continued her rigid implementation of the policy and caused the death of more pregnant women. One of them was Chen Bi's wife, and Chen Bi was the first baby that Gugu had delivered in her career. She brought Chen Bi to life by delivering him into this world, but also ended his hope by forcing him to obey the state one-child policy. She worked like a hound, chasing Chen's wife, till she died on the boat while trying to escape.

Seeing what Gugu had done, her own cousin, Tadpole's father, could not help questioning whether she was still a human being. It is a question worth asking, for what could change a warm-hearted person who once even helped a cow with calfing into such a stone-hearted killer who blocked so many babies' way to life?

The novel depicts Gugu as having a perplexing mind and confusing behavior. She is not a heartless person. When Wang Renmei accepted Gugu's proposal of having the abortion and was left in a dangerous situation on the operating table, it was Gugu who generously donated $600 \mathrm{cc}$ of blood in order to save her life. She also feels guilty about her deed. When Wang Renmei's mother stabbed Gugu's thigh with a pair of scissors and might have been imprisoned, Gugu's reaction was that she felt relieved, as a "blood debt is paid in full" (167). This reaction shows that she is aware of the mistake she has committed. She even told Renmei's mother who stabbed her: "Even if I get tetanus and die, you're not responsible. I want to thank you for stabbing me. I can now cast off my burden and strengthen my beliefs." (167) Psychologically speaking, Gugu's desire to pay back with her own blood functions similarly as that of self-mutilation, and she relies on the body injury to escape her mental dilemma. If this example is not adequate enough to prove that deep in her heart she still cherished the bright side of human nature and respected human life, then the following is another example. She has a belief in her practice that as long as a baby comes out of the mother's body, that baby is a life entitled to the right of survival. Thus she would take care of the illegal baby deserted by parents, for example, Chen Bi's daughter, Chen Mei. Faced with people's hatred towards her, she feels being wronged. That explains why she cried at the grave of Tadpole's mother who died one month after the death of her daughter-in-law, Wang Renmei. Deep in her heart she wanted to be respected as that previous warm-hearted "Wan Xin", a person who sympathized with animals, doted on kids and cared about relatives. 
While forcing people to accept the one-child policy as a government agent, Gugu never reasoned that she might be wrong. The violence of various kinds she suffered from before and during the Cultural Revolution had been rooted in her mind and now started sprouting. The one-child policy deprived Gugu of her sentiments and capacity for sympathy, and completely transformed her into a demon. J. M. Coetzee once used legal illegality to describe third degree tortures in the interrogation room, and revealed that the torture from the policeman resulted in his own suffering from Schizophrenia later. (Coetzee 1992: 368) Gugu is suffering from Schizophrenia of the same category. She believed that she was carrying out the law representing the state will, so her deeds were lawful and justified (legal illegality), while those parents who tried to have another baby became law breakers (illegal legality). What Gugu did and believed in, in fact, was similar to thousands of other population-control officials in China. They face a fatal psychological problem in their sense of morality. As Pufendorf says: "The primary axiom in moral disciplines which look at the subject from the point of view of the human court is held to be: a man may be held accountable for those actions which it is in his power whether they are to be done or not. It comes to the same thing to say: any action which can be under human control and whose commission or non-commission is in his power may be imputed to him. Conversely, no one may be held to be the author of an action which was not in his power either in itself or in its cause." (Pufendorf 1994: 23) Through their loyalty to the Party and adherence to the one-child policy, subconsciously, Gugu and her fellow officials have passed the accountability to the state. But if there is still some benign nature deep inside them, like that policeman mentioned in Coetzee's essay, they may have to suffer from dissociative identity disorder.

Facing the population-control policy, not only Gugu gradually lost her mental faculties, parents of babies also lost their capacity of making righteous judgments. The situation these parents face is similar to what Sophie is confronted with in W. Styron's Sophie's Choice, when she was forced to choose either her son or her daughter to be sent to the gas chamber. Both her options would have equally negative outcomes. Similarly, when parents could only have one baby, they were forced to balance the advantages of having a son or a daughter. The traditional Chinese culture values male children over female. It is a widely-accepted belief among the Chinese that a male child can provide more for the family after he grows up, especially in the field of work ${ }^{8}$, and can also get employment more easily. Therefore, when Chinese parents lost the freedom to have more than one

8 The Chinese character for “male” (男) is composed of “田” (field) and “力” (power). 
child, they desired to have male babies rather than female ones. In the novel, there are examples about the killing of baby girls. Alternatively, some people tried to find medicine to increase the chance of having twins, or secretly appealing to scanning techniques, so as to terminate any female fetus until the arrival of a male one. These are also symptoms of Schizophrenia and this disease generates another serious consequence in the gender imbalance. The Chinese government census data shows that in the early 1980s China's sex ratio at birth was 108 males to every 100 females; in the 1990s the ratio was 117 males to 100 females (Hesketh 2009: 1171-1176), and in the 2010s, the ratio was even higher. And in some provinces, such as Anhui, Jiangxi and Shaanxi, the sex ratio had soared to more than 130 males. It is predictable that in the near future many men in China would have difficulty finding a spouse.

What is discussed above aims to prove that it is predictable that when parents are purposefully choosing the gender of their children, they have been forced to abandon their human nature, which is a fatal mistake; however, the novel Frog shows an ambiguous Chinese-style feeling towards these kind of parents, such as Chen $\mathrm{Bi}$ and Tadpole. Both of their wives died when trying to give birth to another baby boy. They should be criticized, because it is due to their wanting to have another son that their wives died. However, the depiction of these two characters contains touches of melancholy. The novel shows that when confronted with the power of the state, the will of the individual might become powerless. The death of Wang Renmei temporarily wakened Tadpole out of believing in the good intention of this state policy. He started to reflect on the void in his human nature. Then he planned to leave the army and come back to the country to keep company with his father and daughter. But when Gugu informed him that the army had promised to give him a promotion, and subsequently he would have the city identification card $^{9}$, he retrieved his application for quitting military service, and followed Gugu's arrangement of marrying Little Lion. As for Gugu, even though she did feel sad about the death of Wang Renmei, blindly following the state policy, she had lost the capacity of reasoning with her own human nature.

Beside the melancholy touch when depicting those twisted and deformed characters' violence and cruelty during the implementation of the one-child population control policy, the novel Frog does trigger such questions as: How to judge this state policy? Is it civilized or barbaric? Is it a progress of human nature or a retreat? Should parents be forced to make a choice about the gender

$9 \quad$ There was still a huge difference between being a peasant and being a city resident in China, because of the gap in living standards. 
of their babies? These questions may seem easy to answer to readers outside China, but for those inside, it requires courage and tactics. As Coetzee notes, "A work brought out under censorship has a different mode of existence from a work brought out in unrestricted circumstances." (1996: 150) To judge from this perspective, it is understandable that the Narrator said in the letter to Sugitani Akihito sensei, "Over the past two decades China has resolved the problem of its population explosion by draconian measures, not only for the sake of the country's development, but as a contribution to humanity. [...] Once they've gone, they're not coming back, and seen from this perspective, Westerners' critiques of China's family-planning policies are unfair." (171) And compared with all the other novels that have been published inside China in 2009, Mo Yan's Frog is still the most daring one that openly criticized the inappropriateness of the child-control policy, and it has effectively triggered people to think more about the possible side effects that may arise when virtue is set against statehood.

\section{Ending with the Croaks of the Frogs - Virtue Retrieved}

In a ten-hour address to the 1997 Cérisy conference entitled "The Autobiographical Animal," Jacques Derrida mentioned his encounter with a cat. The staring of the cat at the naked philosopher in his bathroom makes him suddenly feel shame and then the philosopher generates his masterpiece - The Animal That Therefore I Am. To Gugu in Frog, the year 1997 also contains the moment of revelation derived from an animal. One night in that year she attended a farewell party and she had been told by the manager of the hospital that she was to retire. After drinking much alcohol at the party, she staggered back to the hospital dormitory along a narrow, winding path bordered on both sides by head-high reeds and croaks of frogs. The croaking frogs came at her from all sides and tore down her dress. "Thousands, tens of thousands of frogs had formed a mighty army behind her, croaking, hopping, colliding, crowding together, like a murky torrent rushing madly towards her." (250) In Mandarin the words "frog" and "baby" sound the same. These frogs symbolize the babies that had been deprived of the right of life by Gugu and the croaks of the frogs are the cries of these babies. The rebellious frogs metaphorically teach Gugu a lesson. Gugu had never been scared before, but that night she was terrorstricken. Here it is the animal's voice, not the animal's gaze that produces a force, making her reflect on her own deeds in the past, which she had thought to be virtuous, but seemed so vicious now. The croaking frogs woke her up and made her listen to the call of her heart. She felt so remorseful about what 
she had done and then she decided to marry Hao Dashou ${ }^{10}$ who was good at making clay dolls.

Gugu's marriage again shocked her relatives. She explained her marriage to them through a DVD she made, which depicted how Hao Dashou helped Gugu make clay baby dolls, each representing the baby whose way to this world had been blocked by Gugu's hands. By relying on the hands of her husband, and making offerings to these clay dolls, Gugu hoped that these babies could get reincarnated and her sin could be atoned for. However, it has been noted that Mo Yan sets this part of the story in a hallucinatory setting which shows his pessimistic view about the redemption of human nature under the state will. Within the state, modern men are doomed to live with a mental dilemma, because "as a citizen of state, men are born subject, from the moment of their birth when they are given a birth certificate which determines their nationality, till the moment of their death, when their name is officially deleted with a death certificate." (2007: 5) In the remote village, when the state will does not go against human nature, Gugu used to be regarded as a blessed bodhisattva, but she could be also turned into a devil to those parents who disobeyed the government policy and wanted to have another child. To formulate a policy, it is dangerous when the government deprives people of their freedom to make their own choices, for the will of the individual is as important as the will of the state, and should be respected. If citizens in China are given the choice of controlling their own reproduction, there would be more space for them to retain the virtue of their human nature, and fulfill their duty as a human: doing no harm to others, being equal to others and helping others, as advocated by Pufendorf. More specifically speaking, they might reconsider the necessity of having a male baby, and nobody would be given a chance to find any legal support for their brutality in depriving other people's rights of having a baby.

At the end of this novel, Mo Yan also depicts a situation in which people have to find surrogate mothers because of their infertility. Nearly a decade after the release of the novel, with the removal of the child-control policy, Chinese readers are faced with the situation that Chinese people no longer want to, or are not able to have a baby at all. In year 2017, coincidentally, there was a mobile phone game called TravelFrog, which became a hit in China, ranking as number one among free games in Apple's App Store. This game is especially popular with female players, and the game involves looking after an adventurous frog by preparing meals for journeys that the baby frog undertakes. The virtual frog then brings back gifts from its travels and also

10 The Chinese character of the given name "Dashou" means "big hands", which implies that he would use his big hands to create clay baby dolls for Gugu. 
sends selfies taken at scenic spots. Although the game is produced by a Japanese company, it has proved to be more popular with female users in China than in its native country, and a very important reason lies in the fact that it helped evoke maternal feelings in women for their virtual babies. And this situation witnesses slight differences between the two sorts of frogs. The frog in Moyan's novel witnesses how the one-child policy affected people's lives, and the frog popular in the 2017 mobile phone app game shows that even if the population control policy has changed, people may still face new challenges, such as prevailing sterility due to lack of food safety, or the high pressure for survival which makes women try to feed babies in the virtual instead of the actual world.

To summarize, this paper suggests reading this novel Frog from three perspectives. Firstly, if this novel is read from the perspective of Gugu, as an individual's history, it reveals the difficulty a person may face while trying to maintain his or her own virtue. Secondly, if this novel is read from the perspective of a nation's history, especially when the family control policy in China is being changed at present yet without seeing much active response, it reveals that any policy should put human life first, for when the welfare of a certain group of people is bought at the cost of numerous deaths, that policy is far from the virtue that human beings are preciously endowed with, and it is doomed to end sooner or later. And, finally, if this novel is read from a global point of view, the world should draw a lesson from viewing the vicious behavior of the hot-headed masses during the Chinese Cultural Revolution. When a huge rally is gathered together, fervently denouncing, humiliating and torturing their fellow citizens, or people from other groups, say Stinking Ninth Category ${ }^{11}$, LGBTs, immigrants, women etc., their opinions definitely are not the golden rule to follow, because any decision-making, no matter whether individual or governmental, should respect people's human dignity and moral rights, or its sustainability would always be in question.

\author{
Wang Jinghui \\ jh.wang@mail.tsinghua.edu.cn \\ Room 317, Wennan Building \\ Tsinghua University \\ Haidan District \\ Beijing 100084 \\ P. R. CHINA
}

11 This is a term of abuse used in the 1966-1976 Chinese Cultural Revolution, which referred to the educated people, belonging to the class of enemies, next to landlords, reactionaries and spies, etc. 
WANG

\section{Bibliography}

Blyth, E.; Frith, L.; Crawshaw, M. 2008. Ethical Objections to Sex Selection for Nonmedical Reasons. - Reproductive Biomedicine Online, Vol.16 Suppl., 41-45.

Coetzee, J.M. 1992. Doubling the Point: Essays and Interviews. Ed. by D. Attwell. Cambridge, MA: Harvard UP.

Coetzee, J. M. 1996. Giving Offense: Essays on Censorship. Chicago: U of Chicago Press.

Coetzee, J. M. 2007. Diary of a Bad Year. Melbourne: The Text Publishing Company.

Derrida, J. 2008. The Animal That Therefore I Am. Ed. by M.-L. Mallet, transl. by D. Wills. New York: Fordham UP.

Ding Qu Jian; Hesketh, T. 2006. Family Size, Fertility Preferences, and Sex Ratio in China in the Era of the One Child Family Policy: Results from National Family Planning and Reproductive Health Survey. - BMJ, 333.7564, 371-373.

Gordon. White. 1976. The Politics of Class and Class Origin: The Case of the Cultural Revolution, Canberra: The Australian National University Press.

Hesketh, T. 2009. Too Many Males in China: the Causes and the Consequences. Significance, 6.1, 9-13.

Hesketh, T.; Zhu Wei Xing. 2006. Abnormal Sex ratios in Human Populations: Causes and Consequences. - Proceedings of the National Academy of Sciences of the United States of America, 103.36, 13271-13275.

Hesketh, T; Li Lu; Zhu Wei Xing. 2009. The Effect of China’s One-child Family Policy after 25 Years. - The New England Journal of Medicine, 353.11, 1171-1176.

Hobbes, T. 1998. On the Citizen. Ed. and transl. by R. Tuck. Cambrigde: Cambridge UP.

Kang C., Wang Y. 2003. Sex Ratio at Birth. - Theses Collection of 2001, National Family Planning and Reproductive Health Survey. Beijing: China Population Publishing House, 88-98.

Klemetti, R. et al. 2010. Cesarean Section Delivery among Primiparous Women in Rural China: an Emerging Epidemic. - American Journal of Obstetrics and Gynecology, 202.1, 65-67.

Lakkaraju, A.; Gupta, P. R.; Gray, E. W. 2009. Human Sex Ratio and Family Size for a Selected Sample from the India Population in 2007-2008. - Journal of The Kentucky Academy of Science, 70.1, 56-62.

Lao Tse. 2008. The Tao Te Ching. Transl. by E. Ryden. Oxford: Oxford UP.

Legge, J., transl. 1963. The I Ching: The Book of Changes. New York: Dover Publications.

Melendez, J. et al. 2007. The Stringless IUCDs of Shanghai: an Educational Tale. Journal of Obstetrics and Gynaecology, 27.4, 441-443.

Melzer, A. M. 1990. The Natural Goodness of Man: On the System of Rousseau's Thought. Chicago: University of Chicago Press.

Mitchell, D.; Duran, A. 2014. A Textbook Case of Comparative Cultural Studies. - A. Duran, Yulan Huang, eds., Mo Yan in Context: Nobel Laureate and Global Story Teller. Este Lafyette: Purdue University Press, 195-212.

Mo Yan. 2009. “蛙”[Frog] - 《收获》 [Harvest], vol. 6, 105-207. 
Virtue or Vice? Trauma Reflected in Mo Yan's Frog

Mo Yan. 2009. Frog. Transl. by H. Goldblatt. London: Penguin Group.

Pufendorf, S. 1991. On the Duty of Man and Citizen According to Natural Law. Ed. by J. Tully, transl. by M. Silverthorne. Cambridge: Cambridge University Press.

Pufendorf, S. 1994. The Political Writings of Samuel Pufendorf. Ed. by C. L. Carr. Oxford: Oxford University Press.

Rousseau, J.-J. 1979. Emile, or On Education. Transl. by A. Bloom. New York: Basic Books.

Styron, W. 1979. Sophie's Choice. New York: Random House.

Wallas, G. 1948. Human Nature in Politics. $4^{\text {th }}$ edition. London: Constable \& Company Ltd.

Zhang Dainian. 1988. 《文化与哲学》 [Culture and Phylosophy]. Beijing: Publishing House of Education and Science. 